\title{
MENGUKUR TINGKAT KESEHATAN KEUANGAN TIGA PERUSAHAAN PROVIDER TERBESAR DI INDONESIA
}

\author{
Diana Riyana H. ${ }^{1)}$ \\ 1) dosen universitas pamulang, email : dhariayanti@yahoo.com
}

\section{ARTICLES \\ INFORMATION}

\section{JURNAL SEKURITAS}

(Saham, Ekonomi, Keuangan dan Investasi )

Vol.1, No.2, September 2018

Halaman : 77-88

C LPPM \& Prodi Manajemen

UNVERSITAS PAMULANG

$$
\begin{array}{ll}
\text { ISSN (online) } & : 2581-2777 \\
\text { ISSN (print) } & : 2581-2696
\end{array}
$$

\section{Keyword :}

Tingkat Kesehatan

Keuangan, Perusahaan

Provider, Rasio Rentabilitas, Rasio Likuiditas, Rasio

Solvabilitas

JEL. classification :

D79, G11, G14, L86, M20

\section{Contact Author :}

PRODI MANAJEMEN UNPAM

JL.Surya Kencana No.1 Pamulang

Tangerang Selatan - Banten

Telp. (021) 7412566, Fax (021) 7412491 Email :

jurnalfinance.unpam@gmail.com
Semakin tingginya kebutuhan masyarakat yang berhubungan dengan paket data dalam berkomunikasi sehingga menjadi peluang bagi perusahaan provider untuk mendapatkan kenaikan jumlah pelanggan yang signifikan dari produk yang ditawarkan. Sehingga melalui jurnal ini, penulis tertarik untuk melakukan pengukuran terkait dengan tingkat kesehatan keuangan dari tiga perusahaan provider terbesar di Indonesia yaitu PT Telkom Indonesia, PT XL Axiata, PT Indosat. Tingkat kesehatan keuangan diukur dengan membandingkan rasio rentabilitas, likuiditas, solvabilitas, dan indicator tambahan yaitu profit margin dan working capital turn over. Dari hasil evaluasi dapat diperoleh informasi perusahaan provider yang mempunyai kategori sehat dan tidak sehat berdasarkan pembobotan dari rasio - rasio keuangan tersebut serta trend kinerja perusahaan dalam periode tahun 2015 - 2017.

The increasing number of data packets comunication so its becomes an opportunity for the provider to get a significant increasing number of customers of the products offered. So through this research journal, writer interested to do research related to financial health level of three biggest provider company in Indonesia that is PT Telkom Indonesia, PT XL Axiata, PT Indosat. The level of financial health is measured by comparing the ratios of profitability, liquidity, solvency, and additional indicators of profit margin and working capital turn over. From the evaluation results can be obtained information provider companies that have healthy and unhealthy categories based on the weighting of the financial ratios and the company's performance trends in the period 2015-2017 


\section{A. Pendahuluan}

Dengan semakin meningkatnya tehnologi komunikasi di era digital, menyebabkan semakin meningkatnya kebutuhan paket data provider di Indonesia. Pada tahun 2017 menurut data dari Asosiasi Penyelenggara Internet Indonesia (APJII) lebih dari 50\% penduduk Indonesia saat ini telah terhubung dengan fasilitas internet dan persentasenya akan cenderung meningkat. Pemanfaatan internet saat ini tidak sekedar untuk kebutuhan komunikasi melainkan banyak digunakan untuk bisnis penjualan, transportasi, promosi, kreativitas dan lain-lain.

Berdasarkan Data Riset Internet World Stat mencatat Indonesia merupakan peringkat keeempat penggunaan internet di Asia.

\section{Jumlah Pengguna Internet Terbanyak di Asia}

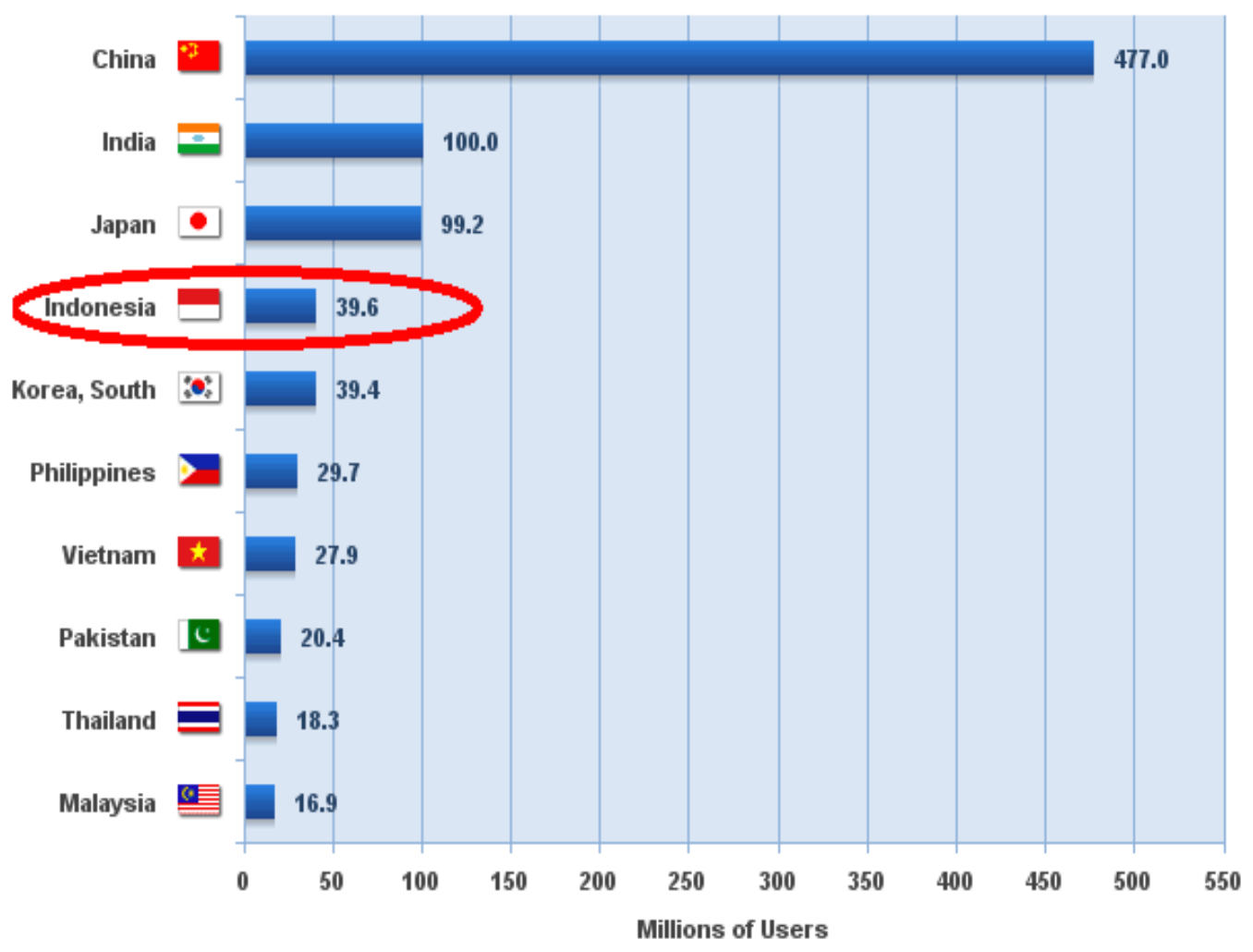

Grafik 1. Tingkat Pengguna Internet di Asia 
Dengan semakin besarnya konsumen pengguna internet menyebabkan perusahaan provider berlomba-lomba menawarkan paket data yang menarik bagi pelanggannya dengan mengemasnya menyesuaikan dengan trend kebutuhan pelanggannya. Dari data yang diperoleh, dari beberapa perusahaan penyedian data internet maka pangsa internet terbesar dikuasai oleh tiga perusahaan nasional yaitu Telkomsel, Indosat dan XL Axiata.

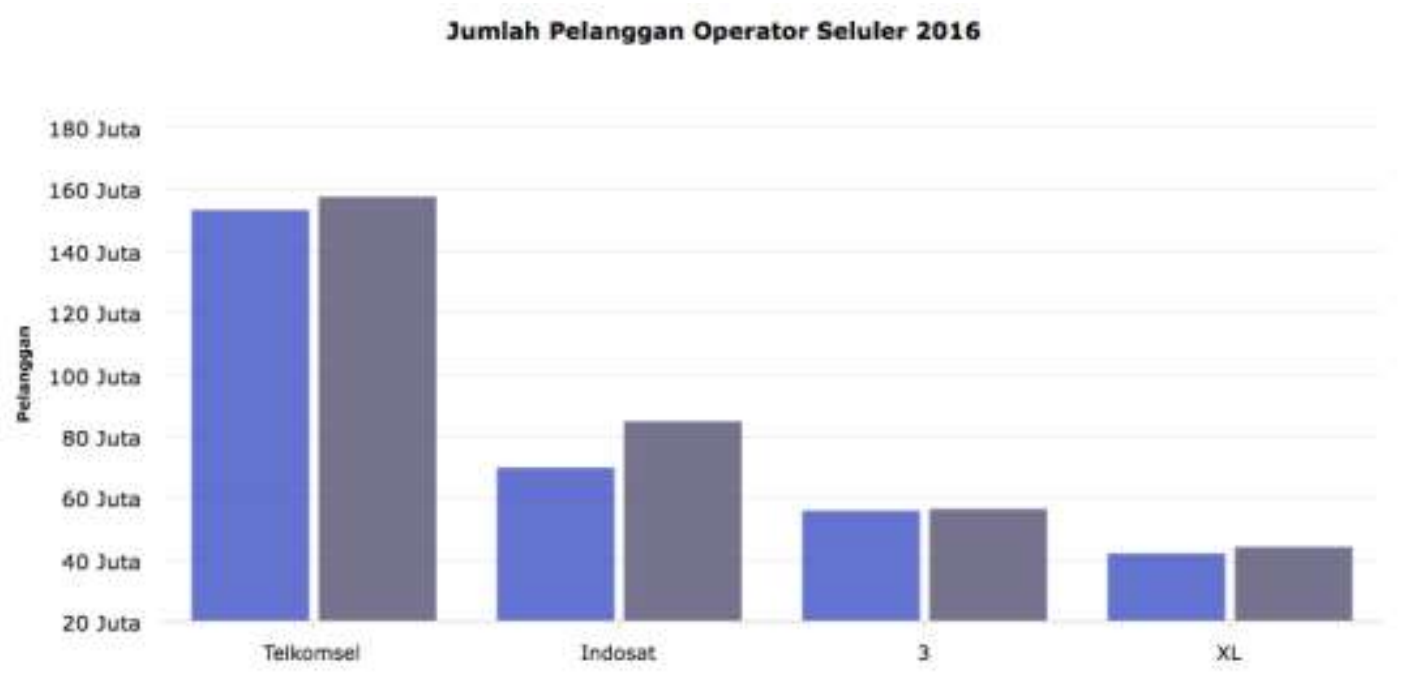

Grafik 2. Perbandingan Jumlah Pelanggan Operator Selular di Indonesia

Melalui jurnal penelitian ini, penulis tertarik untuk meneliti tingkat kesehatan keuangan dari ketiga provider internet terbesar tersebut dengan melakukan pengukuran terhadap rasio rentabilitas, rasio likuiditas, rasio solvabilitas. Selanjutnya hasil pengukuran dari rasio tersebut akan dilanjutkan dengan analisa tingkat kesehatan pada ketiga perusahaan tersebut, yang salah satunya merupakan anak perusahaan BUMN. Sehingga agar perbandingan yang dilakukan selaras maka penilaian kesehatan keuangan dilakukan dengan acuan SK Menteri Keuangan RI No 826/KMK.013/1992 untuk mengukur tingkat kesehatan suatu perusahaan BUMN dengan menetapkan bobot penilaian perusahaan atas rentabilitas, likuiditas, solvabilitas serta indikator tambahan yang ditetapkan dari tahun ke tahun dalam Rapat Umum Pemegang Saham sesuai dengan perkembangan dunia usaha dan perkembangan perusahaan.

\section{B. Perumusan Masalah}

1. Bagaimana rasio rentabilitas dari tiga perusahaan provider

2. Bagaimana rasio likuiditas dari tiga perusahaan provider

3. Bagaimana rasio solvabilitas dari tiga perusahaan provider

4. Bagaimana rasio tambahan : Profit Margin dan Working Capital Turn Over dari tiga perusahaan provider

Jurnal Sekuritas, Vol.1, No.2, September 2018 
5. Bagaimana melakukan pengukuran tingkat kesehatan tiga perusahaan provider berdasarkan pembobotan dari rasio rentabilitas, likuiditas, solvabilitas dan rasio tambahan

\section{Tujuan Penelitian}

1. Mengetahui rasio rentabilitas dari tiga perusahaan provider

2. Mengetahui rasio likuiditas dari tiga perusahaan provider

3. Mengetahui rasio solvabilitas dari tiga perusahaan provider

4. Mengetahui rasio tambahan : Profit Margin dan Working Capital Turn Over dari tiga perusahaan provider

5. Mengetahui hasil pengukuran tingkat kesehatan tiga perusahaan provider berdasarkan pembobotan dari rasio rentabilitas, likuiditas, solvabilitas dan rasio tambahan

\section{Tinjauan Teori}

Menurut SK Menteri Keuangan RI No 826/KMK.013/1992 untuk mengukur tingkat kesehatan suatu perusahaan dengan menetapkan bobot penilaian perusahaan atas rentabilitas, likuiditas, solvabilitas serta indikator tambahan yang ditetapkan dari tahun ke tahun dalam Rapat Umum Pemegang Saham sesuai dengan perkembangan dunia usaha dan perkembangan perusahaan.

1. Rasio Rentabilitas

Rasio ini digunakan untuk mengukur seberapa besar kemampuan perusahaan memperoleh laba dibanding dengan modal sendiri

$$
\text { Rentabilitas }=\frac{\text { Laba sebelum pajak }}{\text { Modal rata }- \text { rata yang digunakan }} \times 100 \%
$$

2. Rasio Likuiditas

Rasio yang digunakan untuk mengukur kemampuan perusahaan dalam memenuhi kewajiban keuangan jangka pendek yang berupa hutang-hutang jangka pendek. Rasio ini ditunjukkan dari besar kecilnya aktiva lancar. Seberapa cepat likuid perusahaan memenuhi kinerja keuangannya, yang umumnya kewajiban jangka pendek (kewajiban kurang dari satu tahun)

Likuiditas $=\frac{\text { Aktiva Lancar }}{\text { Hutang Lancar }} \times 100 \%$

3. Rasio Solvabilitas

Rasio ini digunakan mengukur kemampuan perusahaan untuk memenuhi seluruh kewajiban baik jangka pendek maupun jangka panjang. Seberapa efektif perusahaan menggunakan sumber daya yang dimiliki yaitu sumber daya piutang, modal maupun aktiva.

$$
\text { Solvabilitas }=\frac{\text { Total Aktiva }}{\text { Total Hutang }} \times 100 \%
$$

4. Indikator Tambahan

a. Profit Margin 
ISSN (online) : 2581-2777 \& ISSN (print) : 2581-2696

Perhitungan profit margin dilakukan untuk mengetahui besarnya laba operasi yang dihasilkan dari penjualan bersih.

$$
\text { Profit Margin }=\frac{\text { Laba bersih }}{\text { Penjualan bersih }} \times 100 \%
$$

b. Working Capital Turnover

Working capital turnover perlu dlakukan pengukuran untuk melihat berapa modal kerja yang digunakan perusahan untuk menghasilkan penjualannya. Modal kerja merupakan selisih antara aset lancar dan hutang lancar

$$
\text { Working Capital Turn Over }=\frac{\text { Penjualan Bersih }}{\text { Aset lancar }- \text { Hutang lancar }} \times 100 \%
$$

Keputusan pemerintah yang terkait dengan rasio diatas adalah SK Menteri Keuangan RI No 826/KMK.013/1992 maka bobot dari jenis-jenis indikator kinerja secara keseluruhan yag digunakan untuk penilaian berdasarkan peraturan tersebut adalah :

- Sehat sekali, jika bobot kinerja tahun terakhir adalah diatas 110

- Sehat, jika bobot kinerja tahun terakhir adalah diatas 100 sampai 110

- Kurang sehat, jika bobot kinerja tahun terakhir adalah diatas 90 sampai 100

- Tidak sehat, jika bobot kinerja tahun terakhir adalah kurang dari atau sama dengan 90

Sedangkan untuk mencari bobot penilaian atas kinerja dapat dilakukan dengan memberikan bobot dari rasio yang telah diukur.

\section{E. Metodologi}

Teknik pengumpulan data yang digunakan teknik dokumentasi dengan menggunakan laporan keuangan eksternal yang di publish di web tiga perusahaan provider : PT Telkom Indonesia (TKLM), PT XL Axiata (EXCL), PT Indosat (ISAT).

Teknik analisa data menggunakan analisis deskriptif yaitu suatu kegiatan untuk menyusun, mengklasifikasikan, menafsirkan serta menginterprestasikan data sehingga memberikan suatu gambaran tentang permasalahan yang diteliti. Metode deskriptif pendekatan akuntansi dengan pengukuran tingkat kesehatan keuangan perusahaan dengan rasio rentabilitas, likuiditas, solvabilitas, dan indicator tambahan yaitu profit margin dan working capital turn over.

1. Menghitung rasio rentabilitas dengan membandingkan keuntungan penjualan dengan modal itu sendiri yang terdiri dari aktiva lancar dan aktiva tetap

2. Menghitung rasio likuiditas dengan mengukur kemampuan perusahaan dalam memenuhi kewajiban keuangan jangka pendek yang berupa hutang-hutang jangka pendek

3. Menghitung rasio solvabilitas dengan mengukur kemampuan perusahaan untuk memenuhi seluruh kewajiban baik jangka pendek maupun jangka panjang.

4. Menghitung rasio indikator tambahan yaitu rasio profit margin untuk mengukur besarnya laba operasi yang dihasilkan dari penjualan bersih dan rasio working capital turn over untuk mengukur berapa modal kerja yang digunakan perusahan

Jurnal Sekuritas, Vol.1, No.2, September 2018 
untuk menghasilkan penjualannya.

ISSN (online) : 2581-2777 \& ISSN (print) : 2581-2696

Tabel 1 Definisi dan Metode Pengukuran Tingkat Kesehatan Perusahaan

\begin{tabular}{|c|c|c|c|}
\hline $\begin{array}{l}N \\
0\end{array}$ & Rasio Utama & Dimensi & Keterangan \\
\hline 1 & $\begin{array}{l}\text { Rasio } \\
\text { Rentabilitas }\end{array}$ & $\begin{array}{l}\text { Membandingkan } \\
\text { keuntungan penjualan } \\
\text { dengan modal itu } \\
\text { sendiri yang terdiri dari } \\
\text { aktiva lancar dan aktiva } \\
\text { tetap }\end{array}$ & $\begin{array}{l}\frac{\text { Laba sebelum pajak }}{\text { Modal rata - rata yang digunakan }} \times 100 \% \\
\text { Modal rata-rata = rata-rata aktiva lancar } \\
\text { dan rata-rata aktiva tetap }\end{array}$ \\
\hline 2 & Rasio Likuiditas & \begin{tabular}{lr}
\multicolumn{2}{l}{ Mengukur kemampuan } \\
perusahaan & dalam \\
memenuhi kewajiban \\
keuangan \\
pendek yang berupa \\
hutang-hutang jangka \\
pendek
\end{tabular} & $\frac{\text { Aktiva Lancar }}{\text { Hutang Lancar }} \times 100 \%$ \\
\hline 3 & $\begin{array}{l}\text { Rasio } \\
\text { Solvabilitas }\end{array}$ & $\begin{array}{l}\text { Mengukur kemampuan } \\
\text { perusahaan untuk } \\
\text { memenuhi seluruh } \\
\text { kewajiban baik jangka } \\
\text { pendek maupun jangka } \\
\text { panjang. }\end{array}$ & $\frac{\text { Total Aktiva }}{\text { Total Hutang }} \times 100 \%$ \\
\hline
\end{tabular}

\begin{tabular}{|c|c|c|c|}
\hline No & $\begin{array}{c}\text { Rasio } \\
\text { Tambahan }\end{array}$ & Dimensi & Keterangan \\
\hline 1 & $\begin{array}{ll}\text { Rasio } & \text { Profit } \\
\text { Margin } & \end{array}$ & \begin{tabular}{lr}
\multicolumn{2}{l}{ Mengukur besarnya } \\
laba operasi & yang \\
dihasilkan & dari \\
penjualan bersih &
\end{tabular} & $\frac{\text { Laba bersih }}{\text { Penjualan bersih }} \times 100 \%$ \\
\hline 2 & $\begin{array}{l}\text { Rasio Working } \\
\text { Capital } \\
\text { Turnover }\end{array}$ & $\begin{array}{l}\text { Mengukur berapa modal } \\
\text { kerja yang digunakan } \\
\text { perusahan untuk } \\
\text { menghasilkan } \\
\text { penjualannya }\end{array}$ & $\frac{\text { Penjualan Bersih }}{\text { Aset lancar - Hutang lancar }} \times 100 \%$ \\
\hline
\end{tabular}

Masing-masing rasio diatas diberikan pembobotan dengan memberikan nilai prosentasi pada masing-masing rasio. Rasio yang dianggap lebih utama akan diberikan pembobotan prosentasi yang lebih besar. Setelah diperoleh hasil dari perhitungan masing-masing rasio dikalikan dengan masing-masing bobot pada 
periode 2015 - 2017 maka selanjutnya dilakukan penilaian kinerja dari masingmasing bobot rasio tersebut dengan membandingkan pencapaian tahun tersebut dengan rata-rata kinerja dari ketiga perusahaan provider tersebut.

\section{F. Hasil dan Pembahasan}

Dalam jurnal penelitian ini menggunakan informasi yang terdapat pada laporan keuangan tiga perusahaan provider yang di publikasikan pada IDX dengan periode tahun 2015 - 2017. Untuk menganalisa tingkat kesehatan perusahaan tersebut maka dilakukan pengukuran terhadap rasio utama yaitu rentabilitas, likuiditas, solvabilitas dengan hasil pengamatan pada tabel dibawah ini.

Tabel 2. Hasil Pengukuran Rasio Utama dari Tiga Perusahaan Provider

\begin{tabular}{|c|c|c|c|c|c|c|c|c|c|c|c|c|c|c|c|}
\hline \multirow{3}{*}{ Nb. } & \multirow{3}{*}{$\begin{array}{c}\text { Nama Perusahaan } \\
\text { Provider }\end{array}$} & \multirow{3}{*}{ Tahen } & \multicolumn{13}{|c|}{ Rasio Utama } \\
\hline & & & \multicolumn{5}{|c|}{ Rentabilitas } & \multicolumn{4}{|c|}{ thuidtas } & \multicolumn{4}{|c|}{ Sctrakiitas } \\
\hline & & & $\begin{array}{l}\text { Ikasatein } \\
\text { Pajak }\end{array}$ & Ahbia lanca & Hisia Téa & Fitstias & 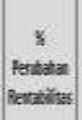 & Anina laves & Hargland & stboidtas & $\begin{array}{c}3 \\
\text { Pertates } \\
\text { Deudian }\end{array}$ & Jotal Latia & Tralhiseg & Solation & $\begin{array}{c}\text { \% } \\
\text { Pontatan } \\
\text { 5olvetilas }\end{array}$ \\
\hline \multirow[t]{4}{*}{1} & TIM & 2015 & $31.342,000$ & 4.108.008 & 99.254500 & 4,66 & \multirow{4}{*}{$3 \%$} & 4.103 .000 & 35,4139920 & 116,07 & \multirow{4}{*}{$\begin{array}{l}48 \\
-138\end{array}$} & 165.173000 & 72745.000 & 228,43 & \multirow{4}{*}{$\begin{array}{l}6 \% \\
-5 \%\end{array}$} \\
\hline & PT. Telom ledresía & 2016 & 38199,000 & 47806.500 & 109.099 .000 & 48,68 & & 47.86 .6500 & 39.7620000 & 120,23 & & 179.611 .000 & $74,067,000$ & 242,50 & \\
\hline & & 2017 & 42.659 .000 & 17.531.002 & 122.334500 & 50,20 & & 47.631.000 & 45.376 .000 & 10497 & & 198.484000 & $86.354,020$ & 229,85 & \\
\hline & Ratarate & & 37.396 .667 & 45513.500 & 110.229333 & 43,02 & & 5513500 & 42.183 .657 & 113,26 & & 181.422657 & 77.72000 & 233,13 & \\
\hline \multirow[t]{4}{*}{2} & EXa & 2015 & [63:526] & 11.730 .674 & 34.316984 & $-2,74$ & \multirow{4}{*}{$\begin{array}{l}132 \% \\
21 \%\end{array}$} & 11.730 .674 & 15.748214 & 74,49 & \multirow{4}{*}{$\begin{array}{l}-21 \% \\
-22 \%\end{array}$} & 58.844214 & 44.752 .585 & 131,29 & \multirow{4}{*}{$\begin{array}{l}24 \% \\
0 \%\end{array}$} \\
\hline & PT. KL Axiata & 2016 & 185.581 & 8.479 .225 & 33.304835 & 0,89 & & 8.479 .225 & $14.477,038$ & 58,57 & & 54,8562286 & 33.687 .141 & 162,96 & \\
\hline & & 2017 & 221.238 & 6993.603 & $34,058.399$ & 1,08 & & 6.993 .803 & 15.226 .516 & 45,93 & & 56.32 .441 & $34,690.591$ & 162,35 & \\
\hline & Ratarate & & $(74,569)$ & 9.057 .900 & 33.393 .476 & 0,35 & & 9.067 .900 & 15.150 .529 & 59,85 & & 56.687344 & 37.710 .139 & 150,32 & \\
\hline \multirow[t]{4}{*}{3.} & ISHT & 2015 & [1.785.855] & 9254.627 & 41.258 .875 & $-7,87$ & \multirow{4}{*}{$\begin{array}{l}20 \% \% \\
16 \%\end{array}$} & 9.254827 & 20,652600 & 46,15 & \multirow{4}{*}{$\begin{array}{l}2 \% \\
15 \%\end{array}$} & 55.368 .517 & 42.124 .676 & 131,19 & \multirow{4}{*}{$\begin{array}{l}5 \% \\
2 \%\end{array}$} \\
\hline & PT. hadosat & 2016 & 1795.263 & 89966.079 & 42.450 .056 & 7,26 & & 89966079 & 190066.592 & 47,13 & & 50.838 .724 & 36.661 .585 & 138,67 & \\
\hline & & 2017 & 1942,426 & 8.776 .376 & 37.455053 & 8,39 & & 8.776 .375 & 16.200 .457 & 5417 & & 50.561 .040 & 35845506 & 141,05 & \\
\hline & Ratarats & & 649.951 & 9.009 .094 & 39.744641 & 2,67 & & $9,0090,094$ & 18.446 .550 & 48,84 & & 52.262 .754 & 38.210 .529 & 136,78 & \\
\hline
\end{tabular}

Dari perhitungan rata-rata maka secara keseluruhan perbandingan dari ketiga perusahaan provider dari pengukuran yang dilakukan terhadap rasio utama yaitu rentabilitas, likuiditas, solvabilitas maka secara keseluruhan PT Telkom mempunyai rata-rata tertinggi dari ketiga rasio pada periode tahun 2015 sampai tahun 2017. Sedangkan PT XL Axiata merupakan rata-rata terbesar kedua untuk rasio likuiditas dan solvabilitas. Sedangkan pada rasio rentabilitas PT XL Axiata pada urutan terendah karena pada tahun 2015 laba sebelum pajak negative.

Sedangkan untuk pembahasan terhadap rasio utama dari masing-masing perusahan adalah sebagai berikut :

- $\quad$ PT Telkom

Rasio rentabilitas PT Telkom mengalami kenaikan dari tahun 2015 sampai tahun 2017. Sedangkan untuk rasio likuditas dan solvabilitas mengalami kenaikan di tahun 2016, namun mengalami penurunan di tahun 2017. 
- PT XL Axiata

Rasio rentabilitas PT XL Axiata kenaikan di tahun 2016 lebih besar daripada tahun 2017 karena laba sebelum pajak di tahun 2015 negatif sehingga menyebabkan ratarata rentabilitas lebih kecil dibanding dengan kompetitor. Sedangkan untuk rasio likuditas cenderung mengalami penurunan dari tahun ke tahun pada periode tahun 2015 sampai tahun 2017. Untuk rasio solvabilitas mengalami kenaikan di tahun 2016, namun cenderung stagnan di tahun 2017.

\section{- PT Indosat}

Rasio rentabilitas PT Indosat mengalami kenaikan cukup signifikan di tahun 2016 sebesar $203 \%$ yang disebabkan laba sebelum pajak di tahun 2016 berubah dari negatif menjadi positif. Sedangkan untuk rasio likuiditas mengalami di tahun 2017 lebih besar dari pada kenaikan di tahun 2016. Untuk rasio solvabilitas kenaikan di tahun 2016 yaitu 5\% lebih besar dari kenaikan di tahun 2017 yang hanya sebesar $2 \%$.

Sedangkan untuk pengukuran rasio tambahan yaitu profit margin dan working capital turnover maka diperoleh informasi seperti pada tabel dibawah ini.

Tabel 3. Hasil Pengukuran Rasio Tambahan dari Tiga Perusahaan Provider

\begin{tabular}{|c|c|c|c|c|c|c|c|c|c|c|c|}
\hline \multirow[b]{3}{*}{ No. } & \multirow[b]{3}{*}{$\begin{array}{l}\text { Nama Perusahaan } \\
\text { Provider }\end{array}$} & \multirow[b]{3}{*}{ Tahun } & \multicolumn{9}{|c|}{ Rasio Tambahan } \\
\hline & & & \multicolumn{4}{|c|}{ Profit Margin } & \multicolumn{5}{|c|}{ Working Capital Turnover } \\
\hline & & & Laba Operasi & Penjualan Bersith & $\begin{array}{l}\text { \% Profit } \\
\text { Margin }\end{array}$ & $\begin{array}{c}\% \\
\text { Perubahan } \\
\text { Profit } \\
\text { Maggin }\end{array}$ & Penjualan Bersih & Aktiva Lancar & Hutang lancar & \begin{tabular}{|c|} 
Working \\
Capital \\
Tamover $(x)$
\end{tabular} & $\begin{array}{c}\text { * } \\
\text { Peratahar } \\
\text { Working } \\
\text { Capital } \\
\text { Tunover }\end{array}$ \\
\hline \multirow[t]{4}{*}{1} & TLKM & 2015 & 32.418 .000 & 102.470 .000 & 31,64 & & 102.470 .000 & 41.103 .000 & 35.413 .000 & 18,01 & \\
\hline & PT. Telkom Indonesia & 2016 & 39.195 .000 & 116.333 .000 & 33,69 & $6 \%$ & 116.333 .000 & 47.806 .500 & 39.762 .000 & 14,46 & $-20 \%$ \\
\hline & & 2017 & 43.933.000 & 128.256 .000 & 34,25 & $2 \%$ & 128.256 .000 & 47.631 .000 & 45.376 .000 & 56,88 & $293 \%$ \\
\hline & Rata-rata & & 38.515 .333 & 115.686 .333 & 33,29 & & 115.686 .333 & 45.513 .500 & 40.183 .667 & 21,71 & \\
\hline \multirow[t]{4}{*}{2} & EXCL & 2015 & 3.139 .277 & 22.876 .182 & 13,72 & & 22.876 .182 & 11.730 .674 & 15.748 .214 & $-5,69$ & \\
\hline & PT. XL Axiata & 2016 & 1.686 .874 & 21.342 .425 & 7,90 & $-42 \%$ & 21.342 .425 & 8.479 .225 & 14.477 .038 & $-3,56$ & $38 \%$ \\
\hline & & 2017 & 1.658 .261 & 22.875 .662 & 7,25 & $-8 \%$ & 22.875 .662 & 6.993 .803 & 15.226 .516 & $-2,78$ & $22 \%$ \\
\hline & Rata-rata & & 2.161 .471 & 22.364 .756 & 9,66 & & 22.364 .756 & 9.067 .900 & 15.150 .589 & $-3,68$ & \\
\hline \multirow[t]{4}{*}{3} & ISAT & 2015 & 2.362 .110 & 26.768 .525 & 8,82 & & 26.768 .525 & 9.254 .827 & 20.052 .600 & $-2,48$ & \\
\hline & PT. Indosat & 2016 & 3.940 .553 & 29.184 .624 & 13,50 & $53 \%$ & 29.184 .624 & 8.996 .079 & 19.086 .592 & $-2,89$ & $-17 \%$ \\
\hline & & 2017 & 4.032 .499 & 29.926 .098 & 13,47 & $0 \%$ & 29.926 .098 & 8.776 .376 & 16.200 .457 & $-4,03$ & $-39 \%$ \\
\hline & Rata-rata & & 3.445 .054 & 28.626 .416 & 12,03 & & 28.626 .416 & 9.009 .094 & 18.446 .550 & $-3,03$ & \\
\hline
\end{tabular}

Dari perhitungan rata-rata maka secara keseluruhan perbandingan dari ketiga perusahaan provider dari pengukuran yang dilakukan terhadap rasio tambahan yaitu profit margin dan working capital turnover maka PT Telkom masih mempunyai ratarata tertinggi dari kedua rasio tersebut pada periode tahun 2015 sampai tahun 2017. Sedangkan PT Indosat merupakan rata-rata terbesar kedua. Namun untuk rasio working capital turn over pada PT XL Axiata dan PT Indosat cenderung negative selama periode tahun 2015 sampai 2017 disebabkan hutang lancar yang dimiliki lebih besar dari pada aktica lancar yang dimiliki.

Jurnal Sekuritas, Vol.1, No.2, September 2018 
Sedangkan untuk pembahasan terhadap rasio tambahan dari masing-masing perusahan adalah sebagai berikut :

- PT Telkom

Rasio profit margin PT Telkom mengalami kenaikan di tahun 2016 namun kenaikan pada tahun 2017 tidak sebesar tahun sebelumnya. Sedangkan pada rasio working capital turnover mengalami penurunan pada tahun 2016 namun mengalami kenaikan yang signifikan di tahun 2017.

- PT XL Axiata

Rasio profit margin mengalami penurunan selama dua periode dari tahun 2015 sampai tahun 2017. Dan untuk rasio working capital cenderung memperkecil nilai negative dari rasio tersebut di tahun 2017.

- PT Indosat

Rasio profit margin PT Indosat mengalami kenaikan di tahun 2016 dan cenderung stagnan pada tahun 2017. Sedangkan untuk rasio working capital turnover cenderung menurun selama dua periode tersebut.

Tahapan selanjutnya dilakukan penilaian atas bobot dari jenis-jenis indikator kinerja secara keseluruhan dari rasio tersebut maka digunakan kategori yang terdapat pada SK Menteri Keuangan RI No 826/KMK.013/1992 sebagai berikut :

\begin{tabular}{|l|l|}
\hline \multicolumn{1}{|c|}{ Kategori } & \multicolumn{1}{c|}{ Keterangan Nilai } \\
\hline Sehat sekali & Jika bobot kinerja tahun terakhir adalah diatas 110 \\
\hline Sehat & Jika bobot kinerja tahun terakhir adalah diatas 100 sampai 110 \\
\hline Kurang Sehat & Jika bobot kinerja tahun terakhir adalah diatas 90 sampai 100 \\
\hline Tidak Sehat & Jika bobot kinerja tahun terakhir adalah kurang dari atau sama dengan 90 \\
\hline
\end{tabular}

$\%$ Bobot yang diberikan untuk rasio utama $70 \%$ yang didistribusikan pada rasio rentabilitas, likuiditas, solvabilitas sedangkan untuk rasio tambahan $30 \%$ yang didistribusikan pada rasio profit margin dan working capital turnover.

Tabel 3. Hasil Pengukuran Kinerja Berdasarkan Perhitungan Rasio Utama dan Tambahan dari Tiga Perusahaan Provider 


\section{TUR⿴囗十丁口八}

Seknumịthes

ISSN (online) : 2581-2777 \& ISSN (print) : 2581-2696

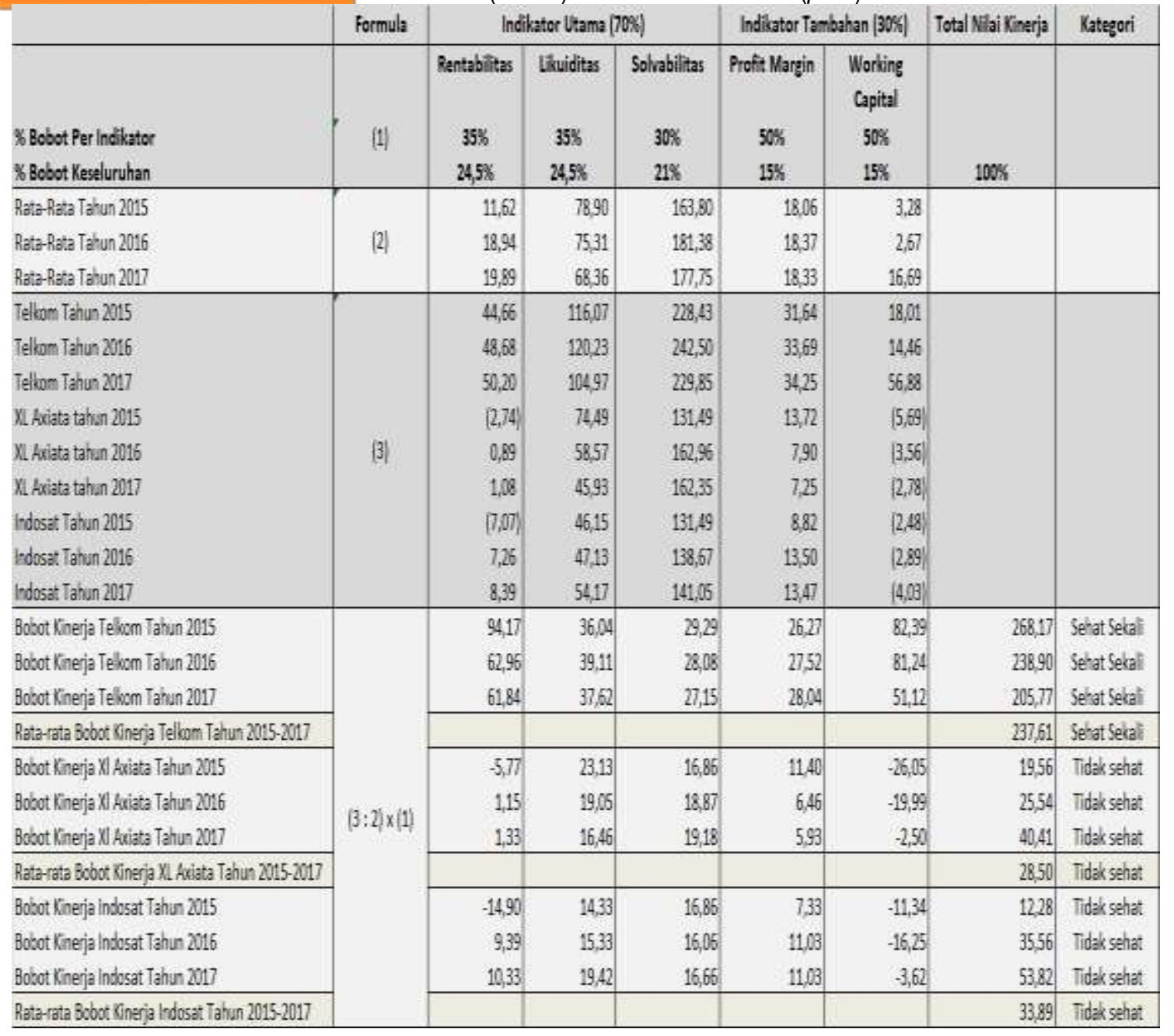

Dari masing-masing rasio dilakukan perhitungan rata-rata dari ketiga perusahaan provider tersebut. Rasio rata-rata tersebut akan dilakukan perbandingan dengan rasio rata-rata untuk mendapatkan bobot kinerja. Penjumlahan dari bobot kinerja tersebut akan menentukan kategori dari tingkat kesehatan keuangan masing-masing perusahaan setiap tahun.

Berdasarkan hasil perhitungan diperoleh bahwa rata-rata bobot kinerja yang mendapat kategori paling sehat adalah PT Telkom selama periode tahun 2015 tahun 2017. Sedangkan PT XL Axiata dan PT Indosat dari hasil pengukuran mendapat rasio tidak sehat untuk kedua periode tahun yang sama. 


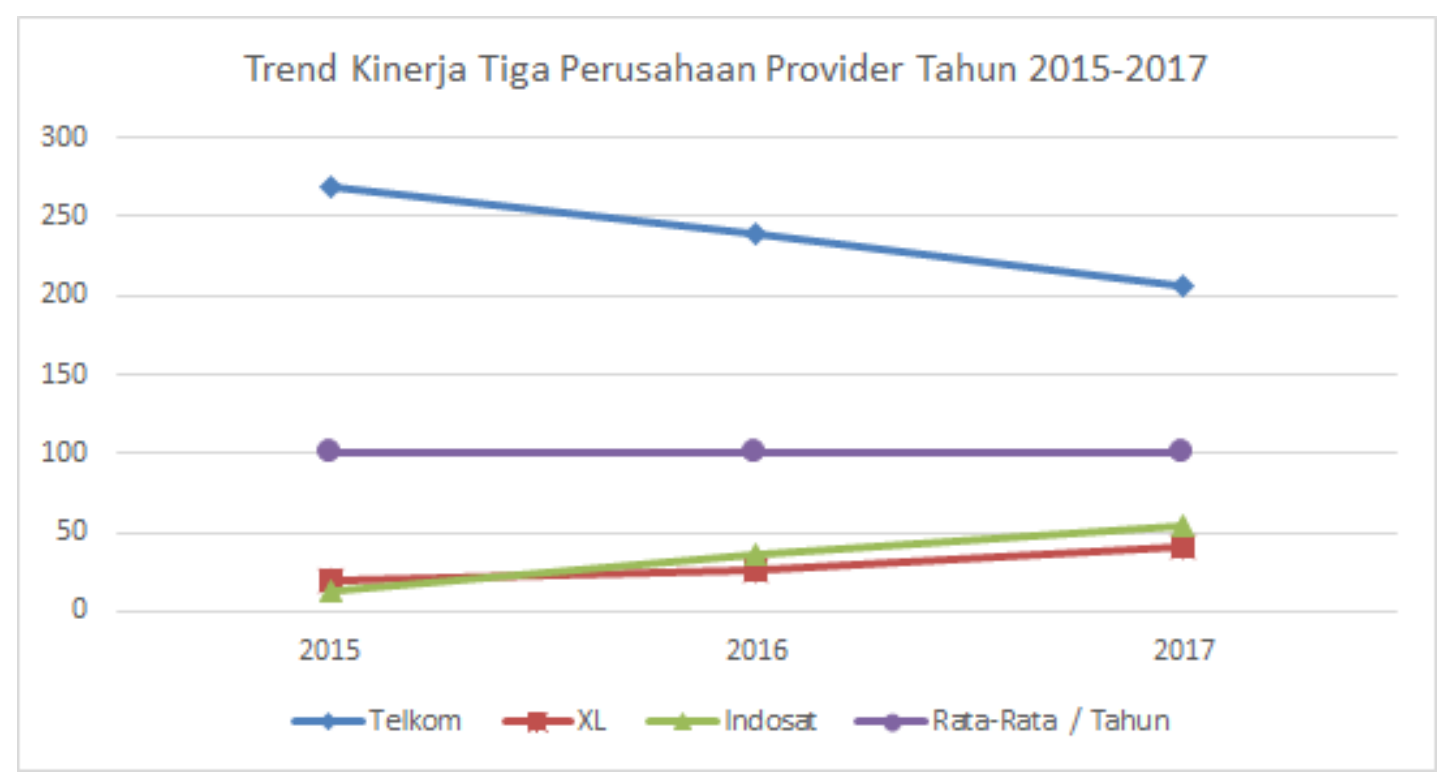

Grafik 3. Grafik Pengukuran Kinerja dari Ketiga Perusahan Provider

Pada grafik hasil pengukuran kinerja untuk ketiga perusahaan provider maka PT Telkom mempunya kinerja jauh diatas rata-rata namun trend kinerja mengalami penurunan dari tahun 2015-2017. Sedangkan PT XL Axiata dan PT Indosat mempunyai kecenderungan mengalami kenaikan kinerja selama 2 tahun pengukuran tersebut, namun cenderung dibawah kinerja rata-rata.

Dari hasil analisa rasio dan tingkat kesehatan yang dilakukan terhadap tiga perusahaan provider di Indonesia diperoleh gambaran bahwa kecenderunngan akan mempunyai nilai hutang yang cukup besar dibanding dengan aktiva, kemungkinan disebabkan adanya investasi yang besar-besaran dalam jaringan komunikasi. Namun diharapkan setelah dilakukan investasi tersebut akan menghasilkan laba perusahaan di tahun kedepannya. Strategi perusahaan provider untuk meminimalkan biaya investasi biasanya dilakukan merger atau kerjasama antar operator selular.

\section{G. Kesimpulan}

Semakin tingginya kebutuhan masyarakat yang berhubungan dengan paket data dalam berkomunikasi sehingga menjadi peluang bagi perusahaan provider untuk mendapatkan kenaikan jumlah pelanggan yang signifikan dari produk yang ditawarkan. Sehingga melalui jurnal ini, penulis tertarik untuk melakukan pengukuran terkait dengan tingkat kesehatan keuangan dari tiga perusahaan provider terbesar di Indonesia yaitu PT Telkom Indonesia, PT XL Axiata, PT Indosat. Tingkat kesehatan keuangan diukur dengan membandingkan rasio rentabilitas, likuiditas, solvabilitas, dan indicator tambahan yaitu profit margin dan working capital turn over. Dari hasil evaluasi dapat diperoleh informasi perusahaan provider yang mempunyai kategori sehat dan tidak sehat berdasarkan pembobotan dari rasio - rasio keuangan tersebut serta trend kinerja perusahaan dalam periode tahun 2015 - 2017. 


\section{G. Daftar Pustaka}

Erik W. Larson, Clifford F.Gray, "Project Management The Managerial Process”, 2013 McGraw-Hill International Edition ( $5^{\text {th }}$ Edition)

Hafidzul Ulum, 2017, Analisis Perbandingan Kinerja Keuangan Perusahaan Telekomunikasi Yang Tercatat di BEI (Studi kasus pada PT Telekomunikasi Indonesia Tbk dan PT. Indosata Tbk periode 2006- 2015)

Hery. 2016. “Analisis Laporan Keuangan”, Jakarta: PT Grasindo.

Isha Kusumastuty, 2013, Penilaian Kinerja Keuangan Perusahaan Melalui Analisis Rasio Pada Perusahaan Telekomunikasi

Nardi Sunardi (2017), Determinan Intelectual Capital dengan Pendekatan iB-VAIC ${ }^{\text {TM }}$ Terhadap Efisiensi Biaya Implikasinya Pada Profitabilitas Perbankan Syariah di Indonesia, Jurnal Sekuritas (Saham, Ekonomi, Keuangan dan Investasi), Vol.1, No.2, Desember 2017, Unversitas Pamulang.

Nardi Sunardi (2018), analisis risk based bank rating (RBBR) untuk mengukur tingkat kesehatan bank syariah di indonesia, Jurnal IImiah Manajemen Forkamma Vol.1, No.2, Februari 2018 Halaman : 20 - 35, Unversitas Pamulang.

Shella Asty Mawarni, Analisis Penilaian Tingkat Kesehatan BUMN Jasa Keuangan Bidang Usaha Peransurasian dan Jasa Penjaminan Periode 2014-2015

Soekarso, 2009, Hubungan Analisis Ration Keuangan Dengan Kesehatan

Perusahaan

Sugiyono, 2012, "Metode Penelitian Kuantitatif Kualitatif dan R\&D, Bandung : Alfabeta

V. Wiratna Sujarweni, " Analisis Laporan Keuangan " Pustaka Baru, 2017

Weston. J.F., E.F.Brigham. 2004. Dasar-dasar Manajemen Keuangan I dan II Edisi 10. Jakarta: Erlangga

Wicak Lingga Bahara, 2015, Analisis Tingkat Kesehatan Perusahaan Dari Aspek Keuangan Berdasarkan Surat Keputusan ,Menteri BUMN Nomor : KEP100/MBU/2022 (Studi Kasus PT Adhi Karya Persero Tbk Periode 2012-2014)

https://id.techinasia.com/laporan-kineria-finansial-xl-telkom-indosat-q3-2014 http://icraindonesia.com/uploaded/Rating\%20Methodology\%20for\%20Mobile\%20Ser vice\%20Providers\%2021Nov2014\%20IND.pdf

http://www.idx.co.id

SK Menteri Keuangan RI No 826/KMK.013/1992 